\title{
Application of Georadar in Areas with Different Vegetation Cover
}

\author{
Fernando Silva Coutinho ${ }^{1}$, Marcos Gervasio Pereira ${ }^{2}$, Juliana de Oliveira Tostes ${ }^{3}$, \\ Márcio Rocha Francelino ${ }^{4}$, João Henrique Gaia-Gomes ${ }^{2}$ \\ ${ }^{1}$ Pessoas, Inovação e Performance (Gestão Aplicada ao Agronegócio) - Prodap, Belo Horizonte/MG, Brasil \\ ${ }^{2}$ Departamento de Solos, Universidade Federal Rural do Rio de Janeiro - UFRRJ, Seropédica/RJ, Brasil \\ ${ }^{3}$ Instituto Federal de Educação Ciência e Tecnologia do Rio de Janeiro - IFRJ, Campus Nilo Peçanha, Pinheiral/RJ, Brasil \\ ${ }^{4}$ Departamento de Solos, Universidade Federal de Viçosa - UFV, Viçosa/MG, Brasil
}

\begin{abstract}
The Atlantic Forest degradation and fragmentation imposes the need for soil and vegetation assessments in order to estimate the environmental vulnerability of the remnants. The objective of this study was to evaluate the georadar applications in areas of Atlantic Forest under different forms of use in Pinheiral, State of Rio de Janeiro, Brazil, through penetrometer impact and ground penetrating radar (GPR). Forest fragments at different stages of regeneration, and pasture and agriculture (perennial and annual) areas were selected for study. Soil characterization was performed through measurements of soil resistance to penetration (SRP) with an impact penetrometer, and the soil properties with a ground penetrating radar (georadar). SRP increased in the forest areas at initial, medium and advanced stages from 2.0 to $2.5,2.0$ to 3.0 and 2.5 to $6.0 \mathrm{MPa}$, respectively. In the perennial and annual agriculture areas, the increase in SRP was due to differences in their mineral composition, and the lowest values found in the annual agriculture area were due to fauna activity. The employment of GPR generated information in a more rapid manner than with the use of impact penetrometer.
\end{abstract}

Keywords: Atlantic Forest, fragmentation, radar.

\section{INTRODUCTION}

The Atlantic Forest was originally present in nearly 98\% of the land of the state of Rio de Janeiro (RJ), considering its different forest formations (Menezes et al., 2009). Brazil had originally about $12 \%$, or $1,290,000 \mathrm{Km}^{2}$, of its territory covered by Atlantic Forest, but this is now mostly fragmented and dispersed throughout the national territory (Varjabedian, 2010). The devastation process, including of areas that should be permanently preserved, has been accelerated over the past 50 years due to urban growth, industrialization, expansion of agropastoral areas, road openings, mineral extraction and electric energy generation and transmission (RMA, 2011).
Among the municipalities of the Paraíba do Sul Valley that present intense soil erosion and land degradation, stands out Pinheiral, with $88 \%$ of its area at high or very high susceptibility to erosion, one of the highest rates among municipalities of the State (CEIVAP, 2002). This shows the importance of studies on soil-vegetation relationships to verify the degradation and recovery levels of forest fragments and their consequent environmental vulnerability.

The georadar or Ground Penetrating Radar (GPR) can complement or replace the information obtained with some soil study methods, especially to evaluate morphological and physical properties and the presence 
of compacted or densified layers in a faster, accurate and non-destructive way. The use of GPR in pedologic studies reduces the number of pit profiles that must be opened and evaluated in a given landscape or topossequence in the traditional geomorpho-pedological approach, providing important information for the analysis of subsoil aspects (Aranha et al., 2002).

The GPR technique allows detecting objects and layers of different materials by contrasting their dielectric properties. The assessments can be performed throughout the studied area and not at specific spots, as it happens in traditional techniques. GPR has been used in the past decade for the research and diagnosis of structural elements in many areas of the construction sector in a non-destructive way, because of its fast data acquisition and low costs compared to other destructive, semi-destructive and non-destructive testing techniques (Cesar et al., 2009). The GPR technique is able to identify compacted soil layers, a parameter that can be related to soil degradation in areas subjected to various coverings and managements. Despite of this potential, only few studies have applied GPR to pedology, which usually involves soil properties such as texture change and water table depth (Lani et al., 2005; Francelino et al., 2007) or location of dense pedogenetic horizons (Ucha et al., 2002).

The objective of this work was to evaluate soil properties in areas with different vegetation covers in the municipality of Pinheiral, State of Rio de Janeiro, Brazil, using georadar and soil resistance to penetration (SRP) measurements.

\section{MATERIAL AND METHODS}

\subsection{Characterization and location of the study area}

The study was conducted in the Ribeirão Cachimbal sub-basin, located on the right margin of the Paraíba do Sul River in the Middle Paraíba region of Rio de Janeiro. The area is located between latitudes $22^{\circ} 33^{\prime} \mathrm{S}$ and $22^{\circ} 38^{\prime} \mathrm{S}$ and longitudes $43^{\circ} 57^{\prime} \mathrm{W}$ and $44^{\circ} 05^{\prime} \mathrm{W}$. Geopolitically, this sub-basin comprises the municipalities of Pinheiral, Piraí and Volta Redonda, RJ, crossed by the BR116 (Presidente Dutra highway). The region has a rainy tropical climate, with monsoon and dry winters (Am) according to Köppen (1948). The area is part of the ecological area of the Atlantic
Forest, whose original vegetation is identified as Lower Montane Rainforest, typical of altitude zones between 300 and 800 meters (Diniz et al., 2013). Soil profiles were described according to Santos et al. (2005) and classified according to Santos et al. (2013) as Cambissolo Háplico Tb Distrófico típico (Inceptisol) (Menezes et al., 2009).

\subsection{Collection and soil sampling}

Six areas were selected with different vegetal coverages and soil managements: Secondary Forest Initial Stage (SFIS), Secondary Forest Medium Stage (SFMS), Secondary Forest Advanced Stage (SFAS), mixed managed pasture (MMP), perennial agriculture (PA) and annual agriculture (AA). For penetration resistance evaluation in each area, one $20 \times 20 \mathrm{~m}$ plot was set at the backslope. A trench was opened for sample collection in the central part of each plot for granulometric, bulk density (Bd) and total organic carbon analyses (EMBRAPA, 1997).

The area in the forest identified as SFAS was the densest and closest to the advanced successional stage described by the CONAMA 06/1994 Resolution (Menezes et al., 2009). The regeneration of this area started after coffee plantations became less practiced in the region. Over 20-meter-high tree species, emerging sciophilus trees and large variety of woody species, with large amount of litter on the soil and intense decomposition were found in this area. The SFMS area had less dense forest and was covered with abandoned pasture until 1985, when initial secondary forest formation took place and has been continued until present, allowing the current successional development (Brasil, 1994). This area presented a shrub-tree landscape with closed canopy, with initial vegetation stratification and emerging shade species (Menezes et al., 2009). The SFIS area was used for pastures and natural vegetation until 1985, managed by simple annual mowing and occasional burnt. Afterwards, the area was occupied by small farmers, but they rarely used the sampled area and, therefore, secondary forest natural regeneration has initiated, with predominance of Heliophila spp. (Menezes et al., 2009).

\subsection{Vegetal coverage}

The MMP area was composed of established (mainly Brachiaria spp.) and unmanaged pastures (Melinis minutiflora, Hyparrhenia spp., Imperata brasiliensis, 
Andropogon bicornis, Paspalum notatum, other native grasses and legumes), at different degradation stages, and use or abandonment levels (Menezes et al., 2009). The perennial and annual agriculture areas were used for orange (Citrus sp.) and cassava (Manihot esculenta) cultivation, respectively, at the time of data collection. Soil management was carried out with low technological level, with hand tools and low use of agricultural inputs such as limestone.

\subsection{GPR calibration}

The calibration consisted in comparing the reflection times in the radar profiles to the depths evaluated with penetrometer. Thus, the pulse propagation speed was estimated settling the depth range in the radargram. Then, the color transformation was performed and a new gain was indicated, but only for visualization, promoting greater contrast between the reflections to facilitate the interpretation of results.

\subsection{Data collection with the use of GPR}

Data were collected in August 2010 with a Ground Penetrating Radar, TerraSIRch SIR-3000 model, with $900 \mathrm{MHz}$ center frequency antenna. According to Boniak et al. (2008), this antenna has better resolution for shallow soils. The GPR was programmed to detect 512 samples per line (graphic representation of the acquired signal) with 16 bits per sample and achieve a 17.5 - nanosecond prospecting. The antenna direction was perpendicular to the profiles. Data were collected continuously through a single scan of $8 \mathrm{~m}$ at each site.

\subsection{Data processing}

The processing and interpretation of radar images (radargrams) were performed in the Advanced Radar Data Analysis (RADAN 6.6) software. The following procedures were performed for each radargram of each site: the radar position (offset adjustment) was corrected to zero in order to adjust the direct wave emitted by the GPR to the soil surface. Subsequently, the signals obtained were converted to the frequency field, observing the spectrum range in which most of the signal was concentrated. This step was necessary for selecting the filters to be applied in each radargram. The chosen filter was the Finite Impulse Response (FIR), which allows filtering selected frequencies without shifting the reflection in time or position. Frequencies that ranged from 400 to $1200 \mathrm{MHz}$ in the data from the $900 \mathrm{MHz}$ antenna were selected for filtering.

An automatic gain of 2 points, which amplified the low and high signs, was applied, because the filter usage decreases the signal energy. The time conversion (nanoseconds) to depth (meters) was made by calibrating a reflector following the Hinkel et al. (2001) method.

The propagation of a high frequency electromagnetic wave in a given area can be described by its velocity and attenuation along its course (Davis \& Annan, 1989). In low-loss conditions, the speed ( $\mathrm{v}$ ) is related to the real part of the dielectric constant $(\mathrm{K})$ of the propagation medium, given by the following expression: $V=c / \sqrt{ } k$, where $c$ is the electromagnetic wave speed in free space.

An impact penetrometer IAA/Planalsucar-Stolf Model with cone angle of $30^{\circ}$ was used to validate the data obtained from the GPR. This instrument allows verifying the SRP of a steel rod after receiving an impact caused by an iron plunger at the top (Costa \& Nishiyama, 2007; Roppa, 2009). The following Equation 1 was used for transforming the readings of resistance into penetration of the equipment $\operatorname{rod}(\mathrm{cm} / \mathrm{impact})$ :

$\mathrm{RP}=\frac{\mathrm{M} \cdot \mathrm{g} \cdot \mathrm{h}}{\mathrm{A} \cdot \mathrm{x}} \times \frac{\mathrm{M}}{\mathrm{M}+\mathrm{m}}+\frac{\mathrm{M}+\mathrm{m}}{\mathrm{A}} \times g$

where $\mathrm{RP}=$ resistance to penetration $(\mathrm{Pa}) ; \mathrm{M}=$ plunger mass $(3.98 \mathrm{~kg}) ; \mathrm{m}=$ mass of the equipment without the plunger $(3.44 \mathrm{~kg}) ; \mathrm{g}=$ acceleration due to gravity $\left(9.81 \mathrm{~m} \mathrm{~s}^{-1}\right) ; \mathrm{h}=$ plunger drop height $(0.40 \mathrm{~m}) ; \mathrm{A}=$ area of the cone penetrating the soil $\left(1.29 \times 10^{-4} \mathrm{~m}^{2}\right)$; and $\mathrm{x}=$ penetration distance after each impact $(\mathrm{m})$.

The number of impacts per decimeter $(\mathrm{dm})$ in the $0-50 \mathrm{~cm}$ depth layer, which had five replicates for each point of GPR reading in the defined portion, were measured and quantified for variation of soil resistance to penetration. For this, the average values of the five replicates were used to compare with the radargram results. The number of impacts per $\mathrm{dm}$ was transformed into $\mathrm{kgf} \mathrm{cm}^{-2}$ according to the equation: $\mathrm{R}\left(\mathrm{kgf} \mathrm{cm}^{-2}\right)=5.8+66.20 \mathrm{~N}$, where $\mathrm{N}$ is the number of impacts per dm (Stolf, 1987). Resistance to penetration was evaluated when the soil has moisture values of approximately $33 \%$, as determined by gravimetric method. The higher soil moisture value was observed in the SFAS area (39\%) and the lowest in the AA area $(27 \%)$ 


\section{RESULTS AND DISCUSSION}

The granulometric analysis (Figure 1) showed textural variations across depth levels in the forest fragment pasture and agriculture areas. Clay content in the surface layer ranged from 220 to $230 \mathrm{~g} \mathrm{~kg}^{-1}$, while in the 20 to $40 \mathrm{~cm}$ layer, ranged from 290 to $335 \mathrm{~g} \mathrm{~kg}^{-1}$. The textural class for all evaluated soil depths was sandy clay loam and the textural variation in the depths was not enough to define textural B horizon (EMBRAPA, 2006).

SRP values were compared to GPR results. The SFIS area had increases in SRP from 2.0 to $3.5 \mathrm{MPa}$, respectively, for the depths of 20 and $40 \mathrm{~cm}$ (Figure 2). This increase may be due to compaction caused by pressure exerted by upper layers, presence of tap roots or clay content variation in the depth levels.

Radargram results in the SFIS area (Figure 3) showed that the soil material is, in general, homogeneous except for some high amplitude hyperboles found, characterizing different materials in the soil mineral substrate. Field observations indicated that these hyperboles represent the signal reflections from the roots in the soil profile. There are few studies that use GPR for root distribution analysis and, therefore, the contrasting dielectric properties between the roots and the surrounding soil matrix is not known. However, based on the fact that the roots have high water content compared to the soil, the contrast between roots and the surrounding soil matrix is based on this difference in water content (Butnor et al., 2001).

The SFMS area had the lowest SRP values compared to the other areas, ranging from 2.0 to $2.5 \mathrm{MPa}$ (Figure 3 ). This result can be explained by the granulometric variations or by the higher total organic carbon (TOC) content (Table 1), which contributed to greater aggregation and lower bulk density (from $1.28 \mathrm{Mg} \mathrm{m}^{-3}$ at $0-5 \mathrm{~cm}^{2}$ to $1.35 \mathrm{Mg} \mathrm{m}^{-3}$ at $20-40 \mathrm{~cm}$, Table 2), as observed in the radargram (Figure 4). Two high and one low amplitude reflections were observed in the radargram (roots and layer of organic material, respectively). The high amplitude reflections correspond to the sections with more organic matter and presence of roots, and hence higher water content, which were recorded as hyperbole. Freeland et al. (2008) evaluated the soil compaction in sport fields with GPR in Knoxville, Tennessee, and observed an increased reflection in areas with higher organic matter content. The low amplitude reflections in the Figure 4 indicate soil material with small granulometric variation and relatively homogeneous composition.

The highest TOC values were observed at the SFAS area, except for the MMP area at the depth of $0-5 \mathrm{~cm}$ (Table 1) and medium soil density in the $0-20 \mathrm{~cm}$ layer (Table 2), which were similar to the other forest
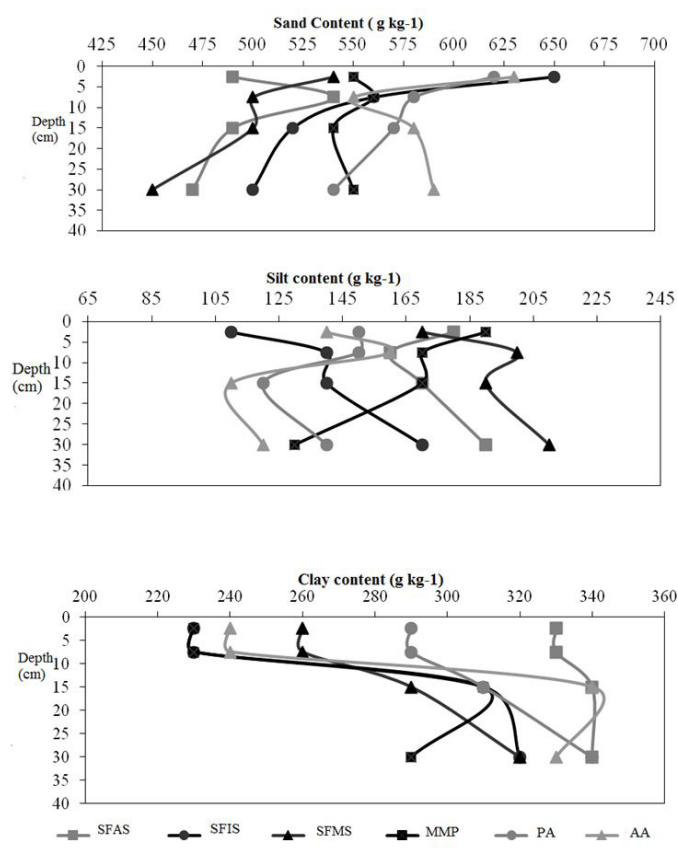

Figure 1. Secondary Forest Initial Stage (SFIS), Secondary Forest Medium Stage (SFMS), Secondary Forest Advanced Stage (SFAS), mixed managed pasture (MMP), perennial agriculture (PA) and annual agriculture (AA).

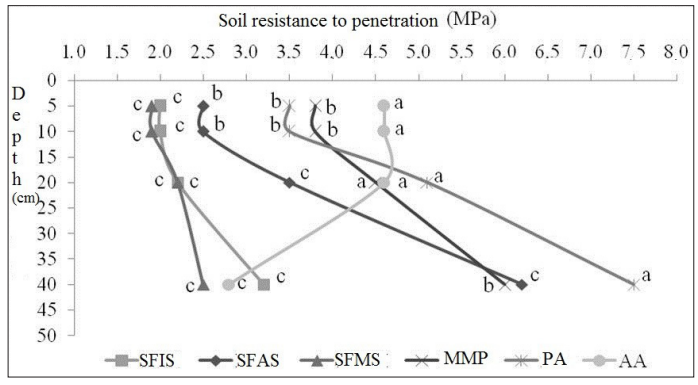

Figure 2. Soil resistance to penetration at different depths in the studied areas. Mean values of five repetitions per area. Different lowercase letters indicate statistical difference between the areas according to Scott Knott test at $5 \%$ probability. SFIS - secondary forest initial stage; SFMS - secondary forest medium stage; SFAS - secondary forest advanced stage; MMP - mixed managed pasture; PA - perennial agriculture; and AA - annual agriculture. 
fragment areas. However, it presented higher SRP in the different depths compared to the other forest fragments. This result can be explained by the higher clay content in all depths, and to the higher incidence

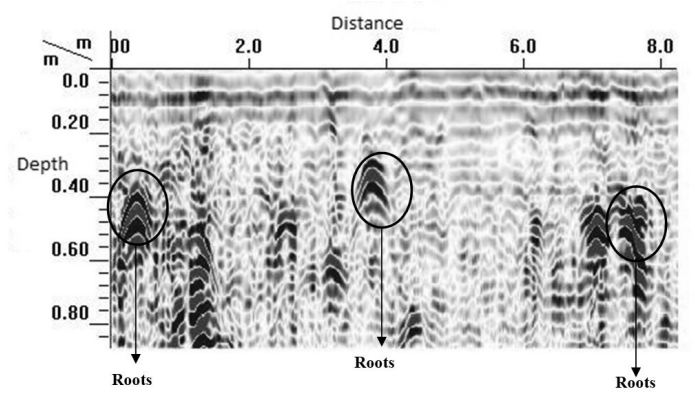

Figure 3. Radargram of the SFIS area. Image obtained with a $900 \mathrm{MHz}$ antenna and time/depth conversion speed of $0.09 \mathrm{~m} \mathrm{~ns}^{-1}$.

Table 1. Mean values ${ }^{(1)}$ of total organic carbon in the areas in Pinheiral, RJ.

\begin{tabular}{ccccc} 
& \multicolumn{4}{c}{ Variables/Depth } \\
\cline { 2 - 5 } Areas $^{(2)}$ COT $\left(\mathbf{g ~ k g} \mathbf{~ k g}^{-1}\right)$ \\
\cline { 2 - 5 } & $\mathbf{0 - 5} \mathbf{~ c m}$ & $\mathbf{5 - 1 0} \mathbf{~ c m}$ & $\mathbf{1 0 - 2 0} \mathbf{~ c m}$ & $\mathbf{2 0 - 4 0 ~ c m ~}$ \\
SFAS & $21.40 \mathrm{ab}$ & $18.18 \mathrm{a}$ & $13.55 \mathrm{a}$ & $11.50 \mathrm{a}$ \\
SFMS & $20.57 \mathrm{ab}$ & $14.60 \mathrm{~b}$ & $13.51 \mathrm{a}$ & $9.57 \mathrm{bc}$ \\
SFIS & $18.62 \mathrm{~b}$ & $13.67 \mathrm{~b}$ & $9.68 \mathrm{~b}$ & $8.72 \mathrm{bc}$ \\
MMP & $22.51 \mathrm{a}$ & $14.25 \mathrm{~b}$ & $11.00 \mathrm{ab}$ & $10.30 \mathrm{ab}$ \\
PA & $12.15 \mathrm{c}$ & $12.36 \mathrm{bc}$ & $9.77 \mathrm{~b}$ & $8.35 \mathrm{c}$ \\
AA & $11.61 \mathrm{c}$ & $9.89 \mathrm{c}$ & $9.32 \mathrm{~b}$ & $9.14 \mathrm{bc}$ \\
\hline
\end{tabular}

(1) Means from the four replications with the same letter on the line did not differ according to Bonferroni test at 5\%; ${ }^{(2)}$ SFIS secondary forest initial stage; SFMS - secondary forest medium stage; SFAS - secondary forest advanced stage; MMP - mixed managed pasture; PA - perennial agriculture; and AA - annual agriculture.

Table 2. Mean values ${ }^{(1)}$ of bulk density $(\mathrm{Bd})$ in the areas in Pinheiral, RJ.

\begin{tabular}{ccccc} 
& \multicolumn{4}{c}{ Depth / Property } \\
\cline { 2 - 5 } Areas $^{(2)}$ & $\mathbf{0 - 5} \mathbf{~ c m}$ & $\mathbf{5 - 1 0} \mathbf{~ c m ~}$ & $\mathbf{1 0 - 2 0} \mathbf{~ c m}$ & $\mathbf{2 0 - 4 0} \mathbf{~ c m}$ \\
\cline { 2 - 5 } & \multicolumn{4}{c}{$\mathbf{B d}\left(\mathbf{M g ~ m} \mathbf{~ m}^{-3}\right)$} \\
SFAS & $1.15 \mathrm{~B}$ & $1.29 \mathrm{~B}$ & $1.34 \mathrm{~B}$ & $1.38 \mathrm{~B}$ \\
SFMS & $1.28 \mathrm{~B}$ & $1.34 \mathrm{~B}$ & $1.35 \mathrm{~B}$ & $1.49 \mathrm{~A}$ \\
\hline SFIS & $1.19 \mathrm{~B}$ & $1.34 \mathrm{~B}$ & $1.39 \mathrm{~B}$ & $1.41 \mathrm{~B}$ \\
MMP & $1.18 \mathrm{~B}$ & $1.34 \mathrm{~B}$ & $1.44 \mathrm{~B}$ & $1.50 \mathrm{~A}$ \\
\hline PA & $1.41 \mathrm{~A}$ & $1.51 \mathrm{~A}$ & $1.52 \mathrm{~A}$ & $1.55 \mathrm{~A}$ \\
$\mathrm{AA}$ & $1.47 \mathrm{~A}$ & $1.50 \mathrm{~A}$ & $1.58 \mathrm{~A}$ & $1.51 \mathrm{~A}$ \\
\hline
\end{tabular}

(1) Different lowercase letters indicate statistical difference between the areas by the Scott Knott test at $5 \%$ probability; (2) SFIS - secondary forest initial stage; SFMS - secondary forest medium stage; SFAS - secondary forest advanced stage; MMP - mixed managed pasture; PA - perennial agriculture; and AA - annual agriculture. of tap roots (Figure 2). The SRP ranged from $2.5 \mathrm{MPa}$ at the $0-5 \mathrm{~cm}$ layer to 3.5 and $6.0 \mathrm{MPa}$ at 20 and $40 \mathrm{~cm}$, respectively (Figure 1). This increase is evidenced in the radargram (Figure 5) by the increase in hyperbolic reflectors, with a high amplitude reflection attributed to the higher amount of roots in the SFAS. The low amplitude reflection, similar to the SFMS, indicates little variation between granulometric fractions. In a study that applied GPR to identify the water table depth in areas with various uses in Seropédica, RJ, Médice (2007) observed an increase in the number of hyperbolic reflectors, which were explained by the interference of large tree roots.

In the MMP area, the comparison between granulometric fraction distributions across depth levels and the SRP (Figure 1) did not show the expected pattern (correlated increase in SRP and clay content). SRP values at depths of $20 \mathrm{~cm}(4.5 \mathrm{MPa})$ and $40 \mathrm{~cm}$ $(6.0 \mathrm{MPa})$ were observed because increasing SRP is associated with increasing clay content. However, increased SRP across the depths was recorded by the radargram in the MMP area (Figure 6), indicating the presence of two layers with contrasting properties, with high and low amplitude reflections, separated at the depth of $40 \mathrm{~cm}$. The low amplitude reflections in the upper layer, as well as in forest fragments, indicate homogeneous characteristics of the soil material with similar electromagnetic response. GPR records are based on clear distinction between materials, and thus, the high amplitude reflection (Figure 5) was attributed to the presence of spots with higher amount of little altered materials (easily weathered rock and mineral fragments at the depth of $40 \mathrm{~cm}$ ).

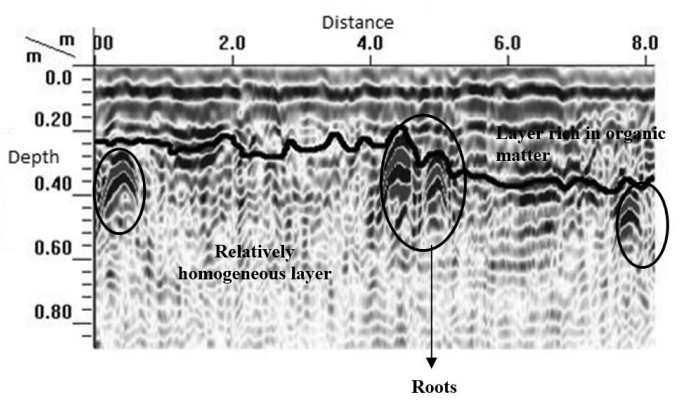

Figure 4. Radargram of the SFMS area. Image obtained with a $900 \mathrm{MHz}$ antenna and time/depth conversion speed of $0.09 \mathrm{~m} \mathrm{~ns}^{-1}$. 


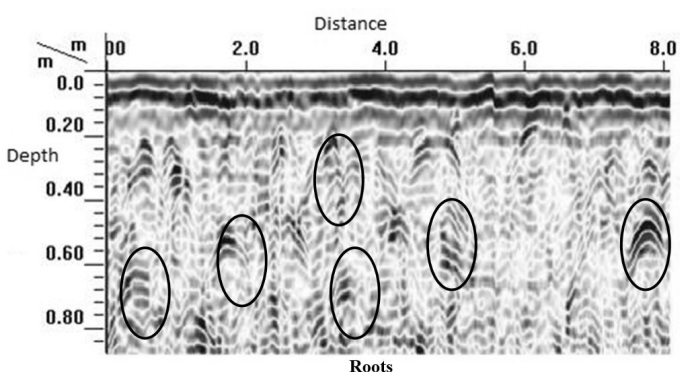

Figure 5. Radargram of the SFAS area. Image obtained with a $900 \mathrm{MHz}$ antenna and time/depth conversion speed of $0.09 \mathrm{~m} \mathrm{~ns}^{-1}$.

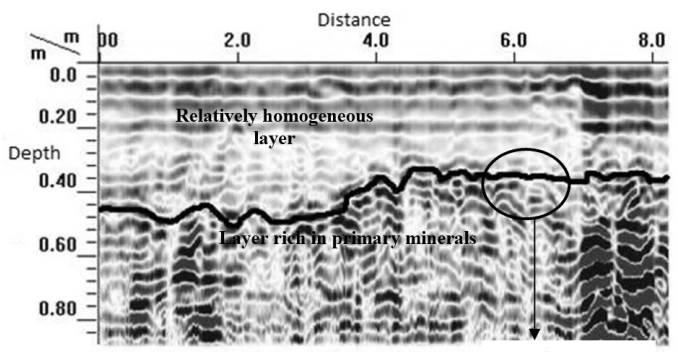

Figure 6. Radargram of the MMP area. Image obtained with a $900 \mathrm{MHz}$ antenna and time/depth conversion speed of $0.09 \mathrm{~m} \mathrm{~ns}^{-1}$.

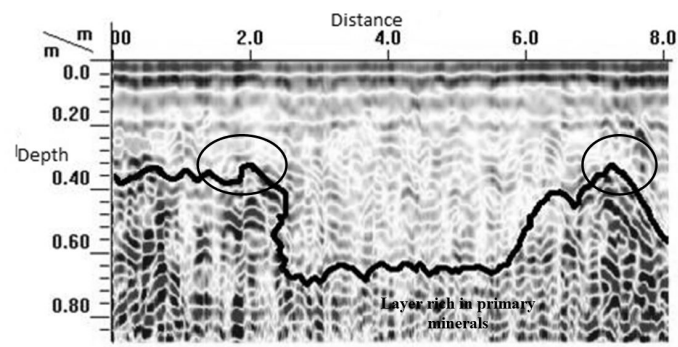

Figure 7. Radargram of the PA area. Image obtained with a $900 \mathrm{MHz}$ antenna and time/depth conversion speed of $0.09 \mathrm{~m} \mathrm{~ns}^{-1}$.

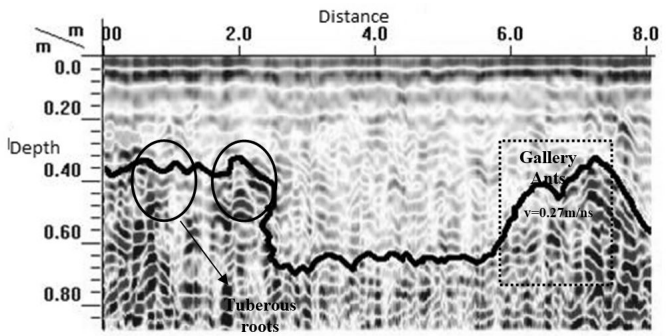

Figure 8. Radargram of the AA area. Image obtained with a $900 \mathrm{MHz}$ antenna and time/depth conversion speed of $0.09 \mathrm{~m} \mathrm{~ns}^{-1}$.
The transition between upper and lower layers displayed a wavy pattern from the depth of 32 to $48 \mathrm{~cm}$, with presence of gravel represented by small hyperbola along the transect (Figure 6). The gravel is mainly composed of primary minerals, which are more resistant to weathering, especially quartz grains, which were found in the field.

Despite the large amount of grass in the MMP area, no pattern caused by the presence of roots was recorded in the radargram. According to Bevan \& Kenyon (1975), fine, shallow roots are not sensed by GPR due to its low reflective power. Another method or an improvement of GPR is necessary to identify these roots (Butnor et al., 2001).

The PA area had the highest SRP values in all the depths in relation to the other areas. SRP values increased from $3.5 \mathrm{MPa}(10 \mathrm{~cm})$ to $5.0 \mathrm{MPa}(20 \mathrm{~cm})$ and $7.0 \mathrm{MPa}(40 \mathrm{~cm})$ (Figure 1), and this increase was proportional to the increase in clay content. The area also had the highest soil density in all depths compared to the forest fragment and MMP areas (Table 2); and the lowest values of TOC at depths of 10-20 and $20-40 \mathrm{~cm}$ (Table 1).

Two distinct layers were observed in the radargram (Figure 7), similar to the MMP area, but with transition at different depths $(28$ and $68 \mathrm{~cm}$ ) and gravel occurring in the section at $20 \mathrm{~cm}$. The radargram image confirms SRP variation; at $40 \mathrm{~cm}$, the top of a layer with different electromagnetic properties from the upper layer was observed, which also presented greater resistance to the penetrometer because of the presence of primary minerals and altered rock fragments.

The AA area presented an increase in subsurface clay, but the SRP variation (Figure 3 ) had the highest value from 0 to $5 \mathrm{~cm}(4.5 \mathrm{MPa})$, with reduction in the depths up to $2.5 \mathrm{MPa}$ at $40 \mathrm{~cm}$. Although an increase in SRP in the annual agricultural area was expected (because of the annual tillage, increase in clay content across depth levels, and SD values ranging from $1.47 \mathrm{~g} \mathrm{~cm}^{-3}$ at $0-5 \mathrm{~cm}$ ) (Table 2), similar to the MMP area, material of greater size and resistance that cause SRP to increase, such as quartz gravel, were found in the surface. The presence of ant nests reduced SRP in the subsurface. Radargram results (Figure 8) confirmed the results of the penetration test, which showed relatively homogenous material at the surface throughout the transect, with low amplitude reflections. High amplitude reflections are characterized by plant tuberous roots 
(hyperbole) and ant nests (semi-hyperbole). These nests were differentiated from the roots by the hyperbole speed variation; the nests had speed of approximately $0.28 \mathrm{~m} \mathrm{~ns}^{-1}$ and the roots of $0.13 \mathrm{~m} \mathrm{~ns}^{-1}$, a number close to the GPR signal speed in the air $\left(\mathrm{v}=0.3 \mathrm{~m} \mathrm{~ns}^{-1}\right.$, Davis \& Annan, 1989).

The $900 \mathrm{MHz}$ antenna used for the georadar measurements was adequate in general to record and identify with high-resolution materials such as roots, gravel and ant nests, and the variations across soil layers.

\section{CONCLUSION}

The root system of the trees in the forest fragment areas promoted an increase in SRP to the depth of 20-40 cm. In turn, in the MMP, PA and AA areas, the presence of large sized minerals influenced the increase in SRP.

The presence of ant nests in the AA area, at the depth of $20-40 \mathrm{~cm}$, led to lower SRP values.

The georadar generated information in a fast, non-destructive and continuous way along a transect, allowing to analyze the soil variations throughout the field work.

GPR use in addition to SRP measurements allowed showing the changes of the edaphic properties across depth levels in the different forest and agricultural areas.

\section{SUBMISSION STATUS}

Received: 13 oct., 2016

Accepted: 27 dec., 2016

\section{CORRESPONDENCE TO}

\section{Marcos Gervasio Pereira}

Departamento de Solos, Universidade Federal Rural do Rio de Janeiro - UFRRJ, BR 465, Km 7, CEP 23890-000, Seropédica, RJ, Brazil e-mail: mgervasiopereira01@gmail.com

\section{REFERENCES}

Aranha PRA, Augustin CHRR, Sobreira FG. The use of GPR for characterizing underground weathered profiles in the sub-humid tropics. Journal of Applied Geophysics 2002; 49(4): 195-210. http://dx.doi.org/10.1016/S09269851(02)00123-4.
Bevan B, Kenyon J. Ground-probing radar for historical archaeology. MASCA 1975; 11(2): 2-7.

Boniak R, Chong SK, Indorante SJ, Doolittle JA. Application of ground-penetrating radar in golf course management. In: Allred BJ, Daniels JJ, Ehsani MR. Handbook of agricultural geophysics. Boca Raton: CRC Press; 2008.

Brasil. Conselho Nacional do Meio Ambiente - CONAMA. Ministério do Meio Ambiente. Resolução $n^{\circ}$ 6, de 4 de maio de 1994. Diário Oficial da República Federativa do Brasil, Brasília, DF (1994 may 30).

Butnor JR, Doolittle JA, Kress L, Cohen S, Johnsen KH. Use of ground-penetrating radar to study tree roots in the southeast tern United States. Tree Physiology 2001; 21(17): 1269-1278. PMid:11696414. http://dx.doi.org/10.1093/ treephys/21.17.1269.

Cesar E, Chicati ML, Fabro FD, Hata FT, Nanni MR, Oliveira RB et al. Uso de GPR na avaliação de atributos de solo em área sob plantio de cana-de-açúcar. In: Anais do XIV Simpósio Brasileiro de Sensoriamento Remoto; 2009; Natal. Natal: INPE; 2009.

Comitê para Integração da Bacia Hidrográfica do Rio Paraíba do Sul - CEIVAP. Diagnóstico da situação atual dos recursos hídricos. Rio de Janeiro: Fundação Coppetec; 2002.

Costa FPM, Nishiyama L. Utilização do permeâmetro de Guelph e penetrômetro de impacto em estudos de uso e ocupação dos solos em bacias hidrográficas. Caminhos de Geografia 2007; 8(24): 131-143.

Davis JL, Annan AP. Ground-penetrating radar for high resolution mapping of soil and rock stratigraphy. Geophysical Prospecting 1989; 37(5): 531-551. http:// dx.doi.org/10.1111/j.1365-2478.1989.tb02221.x.

Diniz AR, Pereira MG, Balieiro FC, Machado DL, Menezes CEG. Precipitaçaõ e aporte de nutrientes em diferentes estádios sucessionais de floresta Atlântica, Pinheiral, RJ. Ciência Florestal 2013; 23(3): 389-399. http://dx.doi. org/10.5902/1980509810550.

Empresa Brasileira de Pesquisa Agropecuária - EMBRAPA. Manual de métodos de análise de solos. 2nd ed. Rio de Janeiro: EMBRAPA; 1997.

Empresa Brasileira de Pesquisa Agropecuária - EMBRAPA. Sistema brasileiro de classificação de solos. 2 nd ed. Rio de Janeiro: EMBRAPA; 2006. 306 p.

Francelino MR, Lani JL, Firme Sá MM, Aranha PRA, Vilarinho, ES. Estudo do lençol freático utilizando radar de penetração do solo. In: Anais do XII Simpósio Brasileiro de Geografia Física Aplicada; 2007; Natal. Natal: INPE; 2007.

Freeland RS, Sorochan JC, Goddard MJ, Mcelroy JS. Using ground penetrating radar to evaluate soil compaction of athletic turfgrass fields. American Society of Agricultural and Biological Engineers 2008; 24: 509-514.

Hinkel KM, Doolittle JA, Bockheim JG, Nelson FE, Paetzold $\mathrm{R}$, Kimble JM et al. Detection of subsurface permafrost features with ground-penetrating radar, Barrow, Alaska. 
Permafrost and Periglacial Processes 2001; 2(2): 179-190. http://dx.doi.org/10.1002/ppp.369.

Köppen W. Climatologia: con un estudio de los climas de la tierra. México: Fundo de Cultura Economica; 1948.

Lani JL, Francelino MR, Aranha PRA, Rosado VB, Vilarinho ES. Uso de GPR na identificação da profundidade do lençol freático e na mudança textural. In: Anais do XXX Congresso Brasileiro de Ciência do Solo; 2005; Recife. Recife: INPE; 2005.

Médice MFS. Estudo da profundidade do lençol freático em áreas com diferentes usos do solo utilizando georadar [monograph]. Seropédica: Instituto de Florestas, Universidade Federal Rural do Rio de Janeiro; 2007.

Menezes CE, Corrêia MEF, Pereira MG, Batista I, Rodrigues $\mathrm{KM}$, Couto WH et al. Macrofauna edáfica em estádios sucessionais de Floresta Estacional Semidecidual e pastagem mista em Pinheiral (RJ). Revista Brasileira de Ciência do Solo 2009; 33(6): 1647-1656. http://dx.doi.org/10.1590/ S0100-06832009000600013.

Redes de ONGS da Mata Atlântica - RMA. O que é biodiversidade? [online]. Brasília: RMA; 2011. [cited 2011 June 22]. Available from: http://www.rma.org.br/ v3/action/node/showNode.php?id=36
Roppa C. Avaliação da dinâmica de restauração de ecossistemas perturbados da Mata Atlântica em uma região de exíguos atributos ambientais, Nova Iguaçu - RJ [dissertation] Seropédica: Instituto de Florestas, Universidade Federal Rural do Rio de Janeiro; 2009.

Santos HG, Jacomine PKT, Anjos LHC, Lumbreras JF, Coelho MR, Almeida JA, Cunha TJF, Oliveira JB. Sistema brasileiro de classificação de solos. Brasília: Embrapa; 2013.

Santos RD, Lemos RC, Santos HG, Ker JC, Anjos LHC. Manual de descrição e coleta de solo no campo. Viçosa: Sociedade Brasileira de Ciência de Solo; 2005.

Stolf R. Teoria e teste experimental de fórmulas de transformação dos dados de penetrômetro de impacto em resistência do solo. Revista Brasileira de Ciência do Solo 1987; 15: 229-235.

Ucha JM, Botelho MA, Vilas Boas GS, Ribeiro LP, Santana PS. Uso do Radar Penetrante no Solo (GPR) na investigação dos solos dos tabuleiros costeiros no litoral norte do estado da Bahia. Revista Brasileira de Ciência do Solo 2002; 26(2): 373-380. http://dx.doi.org/10.1590/ S0100-06832002000200011.

Varjabedian R. Lei da Mata Atlântica: retrocesso ambiental. Estudos Avançados 2010; 24(68): 147-160. 